\title{
Do Public-Private Partnership Investment in Energy and Technological Innovation Matter for Environmental Sustainability in the East Asia and Pacific Region? An Application of a Frequency Domain Causality Test
}

\author{
Tomiwa Sunday Adebayo $^{1}\left(\mathbb{D}\right.$, Sema Yılmaz Genç ${ }^{2}$, Rui Alexandre Castanho ${ }^{3, *(D)}$ and Dervis Kirikkaleli ${ }^{4}(\mathbb{D}$ \\ 1 Department of Business Administration, Faculty of Economics and Administrative Science, Cyprus \\ International University, Northern Cyprus Mersin 10, Nicosia 99010, Turkey; twaikline@gmail.com \\ 2 Department of Marketing and Advertising, Ali Rıza Veziroğlu Vocational School, Kocaeli University, \\ Kocaeli 41780, Turkey; semayilmazgenc@gmail.com or semayilmazgenc@eul.edu.tr \\ 3 Faculty of Applied Sciences, WSB University, 41-300 Dąbrowa Górnicza, Poland \\ 4 Department of Banking and Finance, Faculty of Economics and Administrative Sciences, \\ European University of Lefke, Northern Cyprus, Mersin 10, Lefke 99010, Turkey; dkirikkaleli@eul.edu.tr \\ * Correspondence: acastanho@wsb.edu.pl
}

check for updates

Citation: Adebayo, T.S.; Genç, S.Y.; Castanho, R.A.; Kirikkaleli, D. Do Public-Private Partnership Investment in Energy and Technological Innovation Matter for Environmental Sustainability in the East Asia and Pacific Region? An Application of a Frequency Domain Causality Test. Sustainability 2021, 13, 3039. https://doi.org/10.3390/ su13063039

Academic Editor: José

Manuel Vassallo

Received: 7 February 2021

Accepted: 26 February 2021

Published: 10 March 2021

Publisher's Note: MDPI stays neutral with regard to jurisdictional claims in published maps and institutional affiliations.

Copyright: (C) 2021 by the authors Licensee MDPI, Basel, Switzerland. This article is an open access article distributed under the terms and conditions of the Creative Commons Attribution (CC BY) license (https:/ / creativecommons.org/licenses/by/ $4.0 /)$.

\begin{abstract}
Environmental sustainability is an important issue for current scholars and policymakers in the East Asian and Pacific region. The causal and long-run effects of technological innovation, publicprivate partnership investment in energy, and renewable energy consumption on environmental sustainability in the East Asian and Pacific regions have not been comprehensively explored while taking into account the role of economic growth using quarterly data for the period 1992-2015. Therefore, the present study aims to close this literature gap using econometric approaches, namely Bayer-Hanck cointegration, autoregressive distributed lag (ARDL), dynamic ordinary least square (DOLS), and fully modified ordinary least square (FMOLS) tests. Furthermore, the study utilizes the frequency domain causality test to capture the causal impact of public-private partnership investment in energy, renewable energy consumption, technological innovation, and economic growth on $\mathrm{CO}_{2}$ emissions. The advantage of the frequency domain causality test is that it can capture the causality between short-term, medium-term, and long-term variables. The outcomes of the ARDL, FMOLS and DOLS show that renewable energy consumption and technological innovation mitigate $\mathrm{CO}_{2}$ emissions, while public-private partnership investment in energy and economic growth increase $\mathrm{CO}_{2}$ emissions. Moreover, the frequency causality test outcomes reveal that technological innovation, public-private partnership investment in energy, and renewable energy consumption cause $\mathrm{CO}_{2}$ emissions, particularly in the long-term. Thus, as a policy recommendation, the present study recommends promoting renewable energy consumption by focusing more on technological innovation in the East Asia and Pacific regions.
\end{abstract}

Keywords: environmental sustainability; public-private partnership in energy; renewable energy consumption; economic growth; technological innovation

JEL Classification: C01; Q01; Q28; Q53; Q56

\section{Introduction}

Climate change is currently one of the main obstacles to achieving environmental sustainability globally [1]. Climate change can damage biodiversity, can reduce world food supplies, can lead to escalating sea levels, and can increase disease morbidity and mortality. The primary consequence of these unavoidable hazards is the tremendous volume of greenhouse gas emissions (GHGs) generated by burning fossil fuels, including oil and coal, damaging habitats, including forests. The increases in consumption and 
production rates and countries' efforts to achieve fast economic growth have led to a significant increase in global emissions [2-4]. Technological innovation adds stability to the economic environment and encourages nations to implement modern development strategies that diminish $\mathrm{CO}_{2}$ emissions [4]. Likewise, a technological transition occurs when modifying the input combination, which decreases the energy demand per unit output, and thereby decreases $\mathrm{CO}_{2}$ emissions [5,6]. The capital structure could also reduce the intensity of $\mathrm{CO}_{2}$ emissions [3,6]. However, this impact is significantly reduced when carbon reduction infrastructure schemes are implemented nationally $[5,7]$. Therefore, it is essential to decentralize energy production within the framework of a public and private partnership that allows private parties to invest effectively in renewable energy. Some East Asian and Pacific countries (e.g countries such as Australia, Cambodia, China, Indonesia, Malaysia, Japan, South Korea, Mongolia, New Zealand, Philippines, North Korea, Singapore, Taiwan, Thailand, and Vietnam) contribute significantly to $\mathrm{CO}_{2}$ emissions globally. For instance, in 2018, five of the top 15 highest emitting countries were found in this region. China's global share is $28 \%$, followed by Japan at $3 \%$, Indonesia at $2 \%$, and South Korea and Australia at $1 \%$ each [8]. In 2016, $\mathrm{CO}_{2}$ emissions in East Asia and the Pacific totaled 6.02 metric tonnes, representing a decrease of $1.94 \%$ compared to 2015 [9].

According to studies reported by the Intergovernmental Panel on Climate Change (IPCC), in contrast to past industrial cycles, global warming triggered by human activities has induced mean temperatures to increase by around $1^{\circ} \mathrm{C}$. Extreme weather events, the depletion of Arctic sea ice, and other adverse shifts have all been seen as the results of ongoing global warming. If this surge in emissions occurs in its present form, climatechange-induced temperature changes will exceed the $1.5^{\circ} \mathrm{C}$ level between 2030 and 2052. It is predicted that global warming over $1.5^{\circ} \mathrm{C}$ would lead to the destruction of several ecosystems [10]. Greenhouse gas (GHG) pollution, mainly $\mathrm{CO}_{2}$ emissions, is understood to be the significant factor triggering climate change. As the harmful effects of environmental destruction, including global warming and climate change over time, have started to be witnessed internationally, this topic has inspired policymakers to seek a common solution.

At both domestic and international levels, several conferences on sustainable economic development have been held. These environmental concerns have begun to be tackled by the global community, which has resulted in increased ecological recognition and many international treaties, such as the Kyoto Protocol, which the Paris Agreement accompanied. These efforts to achieve sustainable development and improve environmental awareness have prompted countries to follow ecological norms and climate protection procedures. The remarkable truths that have surfaced from the Kyoto Agreement have transitioned energy production from the conventional direction to more sustainable energy sources. This scenario emphasizes the significance of public-private energy partnerships in renewable energy projects. Public-private partnership Investment in Energy apply to long-term arrangements between public and private institutions to guarantee important general services and goods to residents. Recently, the strategy of public-private partnership Investment in Energy has been advocated by the governments of several countries involved for projects related to energy, transport, expenditure, and construction in other low-carbon sectors [11-14]. Likewise, technological developments are one of the objectives of most East Asian and Pacific countries.

Recently, attention has shifted to the linkage between public-private partnership investment in energy and $\mathrm{CO}_{2}$ emissions by recognizing the influence of technology advancement. For instance, Khan et al. [7] investigated the impacts of technology innovation and public-private partnership investment in energy on China's $\mathrm{CO}_{2}$ emissions using quarterly data from 1990 to 2017. Using recent developed econometric techniques, the empirical findings revealed cointegration amongst the variables. Additionally, technological innovation reduces $\mathrm{CO}_{2}$ emissions, while public-private partnership investment in energy have a positive impact on $\mathrm{CO}_{2}$ emissions. Studies by several researchers $[15,16]$ demonstrate that R\&D stimulates innovation in energy investment that determines the path of technological advancement. Ganda [17] investigated the impacts of innovation and 
renewable technology resources on environmental sustainability in OECD countries. The empirical results showed that technological innovation negatively impacts $\mathrm{CO}_{2}$ emissions, which implies that an increase in technological innovation aids in mitigating environmental degradation. The investigator also noted that while innovation and technical expenditure results are not homogeneous across nations, such tools could be utilized to minimize environmental degradation.

Verdolini et al. [18] explored power generation via innovative fossil-fuel-based technologies in order to promote investment in clean energies in OECD nations. The results indicated that on average, 6 to $14 \mathrm{KW}$ per thousand $\mathrm{KW}$ was correlated with a change from the first to the third quartile of advanced carbon production, with substantial annual renewable energy investment. Thus, equivalent investment in different energy technologies may also reduce emissions [18]. Popp et al. [19] found that technological advancements positively affect investments in renewable energy projects in OECD economies. The investigators showed that renewable energy policies significantly influence renewable energy projects. Using the OECD nations as an example, [20] assessed the effects of public spending on innovation in energy. The empirical findings revealed that energy innovation improves environmental sustainability. The authors mentioned that the amount of a public budget distributed to energy $\mathrm{R} \& \mathrm{D}$ decreases $\mathrm{CO}_{2}$ emissions and contributes towards environmental sustainability.

Shahbaz et al. [5] assessed the interconnections between Public-Private Partnership Investment in Energy and $\mathrm{CO}_{2}$ emissions, taking into account the important role of technological innovations on $\mathrm{CO}_{2}$ emissions. The outcomes indicate that public-private partnership investment in energy hinder environmental sustainability by increasing $\mathrm{CO}_{2}$ emissions; in contrast, innovation mitigates $\mathrm{CO}_{2}$ emissions. Shahbaz et al. [21] researched the determinants of environmental sustainability. The authors established that public energy funding supports energy efficiency in infrastructure, which increases environmental quality by mitigating $\mathrm{CO}_{2}$ emissions. Using the South Asian Association for Regional Cooperation nations as an example, [22] researched the interconnection between $\mathrm{CO}_{2}$ emissions and private investment. The authors used foreign direct investment inflows as metrics for private investment, and the findings revealed that initially private investment promotes $\mathrm{CO}_{2}$ emissions, however at a particular stage the amount of investment reduces carbon emissions, i.e., the inverted-U interaction. Recently, [23] examined the associations between Public-Private Partnership Investment in Energy and $\mathrm{CO}_{2}$ emissions in India between 1990 and 2015 using quarterly data. The investigators employed the Fully modified ordinary least square, dynamic ordinary least square, and frequency domain causality tests to investigate these connections. The empirical findings showed that public-private partnership investment in energy exert negative impacts on $\mathrm{CO}_{2}$ emissions, implying that Public-Private Partnership Investment in Energy improve environmental quality.

The study by [2] on the linkage between $\mathrm{CO}_{2}$ emissions and innovation using global data established that renewable energy usage and innovation reduce $\mathrm{CO}_{2}$ emissions globally. This infers that renewable energy usage mitigates environmental hazards. Using Malaysia as an example, [24] examined determinants of environmental degradation using yearly data for the period between 1970 and 2016. The empirical outcomes established that an increase in environmental deterioration accompanies an increase in economic growth. Moreover, [25] confirmed that the environmental Kuznet curve (EKC)hypothesis validity and public energy spending is closely connected to environmental quality. Technology advances are recognized to have a detrimental effect on $\mathrm{CO}_{2}$ emissions. Khan et al. [7] explored the linkage between international trade and $\mathrm{CO}_{2}$ emissions using yearly data spanning between 1990 and 2018, investigating nine oil-exporting economies. The empirical findings demonstrated that economic growth and imports cause harm to the quality of the environment. In Thailand, [26] assessed the association between trade openness and $\mathrm{CO}_{2}$ emissions. The investigators used a wavelet and autoregressive distributed lag (ARDL) approach to establish this association. The empirical outcomes showed that trade mitigates the $\mathrm{CO}_{2}$ emissions, while economic growth harms the environment. 
The study by [27] in China established that economic growth reduces environmental sustainability, whereas renewable energy usage enhances environmental sustainability. Using China and data from 1990 to 2017, [28] assessed the dynamics among technological innovation, $\mathrm{CO}_{2}$ emissions, and financial development. The researchers utilized recent econometric techniques, with the findings showing that innovation and green energy usage enhance the quality of the environment, while economic growth and financial development worsen the environment's quality. The research by [29] on the link between $\mathrm{CO}_{2}$ emissions and technological innovation in China using data between 1997 and 2015 established negative interconnections between technological innovation and $\mathrm{CO}_{2}$ emissions. The reason for using the East Asia and Pacific regions as a case study is because they are the top-emitting regions globally, emitting 6.07 metric tons per capita in 2016 [9]. Furthermore, these regions are different from other regions because they comprise top-emitting countries such as China (1st), Japan (5th), South Korea (8th), Indonesia (10th), and Australia (16th). Based on the reviewed literature, there is no consensus on the linkages between $\mathrm{CO}_{2}$ emissions and public-private partnership in energy, technological innovation, renewable energy usage, and economic growth, giving room for further analysis of these associations.

The next section covers the data and methodology. The fourth section discusses the findings, while the fifth section provides conclusions and proposes a policy path.

\section{Data and Methodology}

\subsection{Data}

The current research investigates the impacts of public-private partnership investment in energy, renewable energy consumption, technological innovation, and economic growth on $\mathrm{CO}_{2}$ emissions between 1991 and 2015 using quarterly data in the context of East Asia and the Pacific region. Due to the limited sample size, this analysis utilizes a quadratic match-sum technique in transforming yearly data to quarterly data. This conversion approach has been used in prior studies $[4,5,9,10]$. This approach is efficient when decreasing point-to-point adjustments and changing seasonal disparities via the transition of low- to high-frequency data. The utilized series are transformed into a log form. This is done to ensure that data fulfill normality requirements [30-34]. In this paper, the dependent variable is $\mathrm{CO}_{2}$ emissions, while the regressors are public-private partnerships in energy, renewable energy, technological innovation, and economic growth. Table 1 depicts the data measurements, units, and sources, while Figure 1 illustrates the analysis flow. The econometric model of the present study is portrayed in Equation (3):

$$
\begin{gathered}
\mathrm{CO}_{2 \mathrm{t}}=\mathrm{f}\left(\mathrm{GDP}_{\mathrm{t}}, \mathrm{PPIE}_{\mathrm{t}}, \mathrm{REN}_{\mathrm{t}}, \mathrm{TI}_{\mathrm{t}}\right) \\
\mathrm{CO}_{2 \mathrm{t}}=\vartheta_{0}+\vartheta_{1} \mathrm{GDP}_{\mathrm{t}}+\vartheta_{2} \mathrm{PPIE}_{\mathrm{t}}+\vartheta_{3} \mathrm{REN}_{\mathrm{t}}+\vartheta_{4} \mathrm{TI}_{\mathrm{t}} \\
\mathrm{CO}_{2 \mathrm{t}}=\vartheta_{0}+\vartheta_{1} \mathrm{GDP}_{\mathrm{t}}+\vartheta_{2} \mathrm{PPIE}_{\mathrm{t}}+\vartheta_{3} \mathrm{REN}_{\mathrm{t}}+\vartheta_{4} \mathrm{TI}_{\mathrm{t}}+\varepsilon_{\mathrm{t}}
\end{gathered}
$$

In Equation (3), PPIE, $\mathrm{CO}_{2}$, REN, PPIE, TI, and GDP illustrate public-private partnerships in energy, $\mathrm{CO}_{2}$ emissions, renewable energy, technological innovation, and real growth. Furthermore, in Equation (3), $\vartheta_{0}$ shows the constant term, $\vartheta_{i}(i=1 \ldots 4)$ depicts the coefficients of exogenous variables, while $t$ and $\varepsilon$ represent time and error terms, respectively. Though numerous studies have been conducted on the impact of renewable energy consumption, economic growth, technological innovation, and Public-Private Partnership Investment in Energy on $\mathrm{CO}_{2}$ emissions [2,6,34,35], none of these studies used East Asia and the Pacific region as the study group. 
Hypothesis 1. Economic growth has a positive impact on $\mathrm{CO}_{2}$ emissions.

Centered on past results, real growth is expected to significantly affect $\mathrm{CO}_{2}$ emissions [36-39]. Thus, an upsurge in GDP will decrease environmental sustainability, i.e., $\left(\vartheta_{1}=\frac{\partial \mathrm{CO}_{2}}{\partial \mathrm{GDP}}>0\right)$.

Hypothesis 2. Renewable energy consumption has a negative impact on $\mathrm{CO}_{2}$ emissions.

Renewable energy consumption will reduce $\mathrm{CO}_{2}$ emissions. Therefore, an increase in renewable energy is expected to increase environmental sustainability, i.e., $\left(\vartheta_{2}=\frac{\partial \mathrm{CO}_{2}}{\partial \mathrm{REN}}<0\right)$.

Hypothesis 3. Technological innovation has a negative impact on $\mathrm{CO}_{2}$ emissions.

Additionally, technological innovation is expected to minimize $\mathrm{CO}_{2}$ emissions if it is eco-friendly $[5,7,10]$. Hence, an increase in Technological innovation will enhance environmental sustainability, i.e., $\left(\vartheta_{4}=\frac{\partial \mathrm{CO}_{2}}{\partial \mathrm{TI}}<0\right)$.

Hypothesis 4. Public-private partnership investment in energy has a negative impact on $\mathrm{CO}_{2}$ emissions.

This research also examines the interactions between Public-private partnership investment in energy and $\mathrm{CO}_{2}$ emissions. The linkage between Public-private partnership investment in energy and $\mathrm{CO}_{2}$ is expected to be negative, which implies that an increase in public-private partnership investment in energy will enhance environmental sustainability, i.e., $\left(\vartheta_{3}=\frac{\partial \mathrm{CO}_{2}}{\partial \mathrm{PPIE}}<0\right)$.

Table 1. Indicators, sources, and units.

\begin{tabular}{cccc}
\hline Indicator & Description & Units & Sources \\
\hline $\mathrm{CO}_{2}$ & $\begin{array}{c}\text { Environmental } \\
\text { Sustainability }\end{array}$ & Metric Tonnes Per Capita & $\begin{array}{c}\text { World Development } \\
\text { Indicator, [9] }\end{array}$ \\
\hline $\mathrm{TI}$ & $\begin{array}{c}\text { Technological } \\
\text { Innovation }\end{array}$ & $\begin{array}{c}\text { Measured as the addition } \\
\text { of patent applications by } \\
\text { residents and patent } \\
\text { applications by } \\
\text { non-residents }\end{array}$ & $\begin{array}{c}\text { World Development } \\
\text { Indicator, [9] }\end{array}$ \\
\hline GDP & Economic Growth & $\begin{array}{c}\text { GDP Per Capita Constant } \\
\text { \$US, 2010 }\end{array}$ & $\begin{array}{c}\text { World Development } \\
\text { Indicator, [9] }\end{array}$ \\
\hline REN & Renewable Energy & $\begin{array}{c}\text { \% of final energy } \\
\text { consumption }\end{array}$ & $\begin{array}{c}\text { World Development } \\
\text { Indicator, [9] }\end{array}$ \\
\hline PPIE & $\begin{array}{c}\text { Public-private } \\
\text { partnership }\end{array}$ & Current \$US & $\begin{array}{c}\text { World Development } \\
\text { Indicator, [9] }\end{array}$ \\
\hline
\end{tabular}




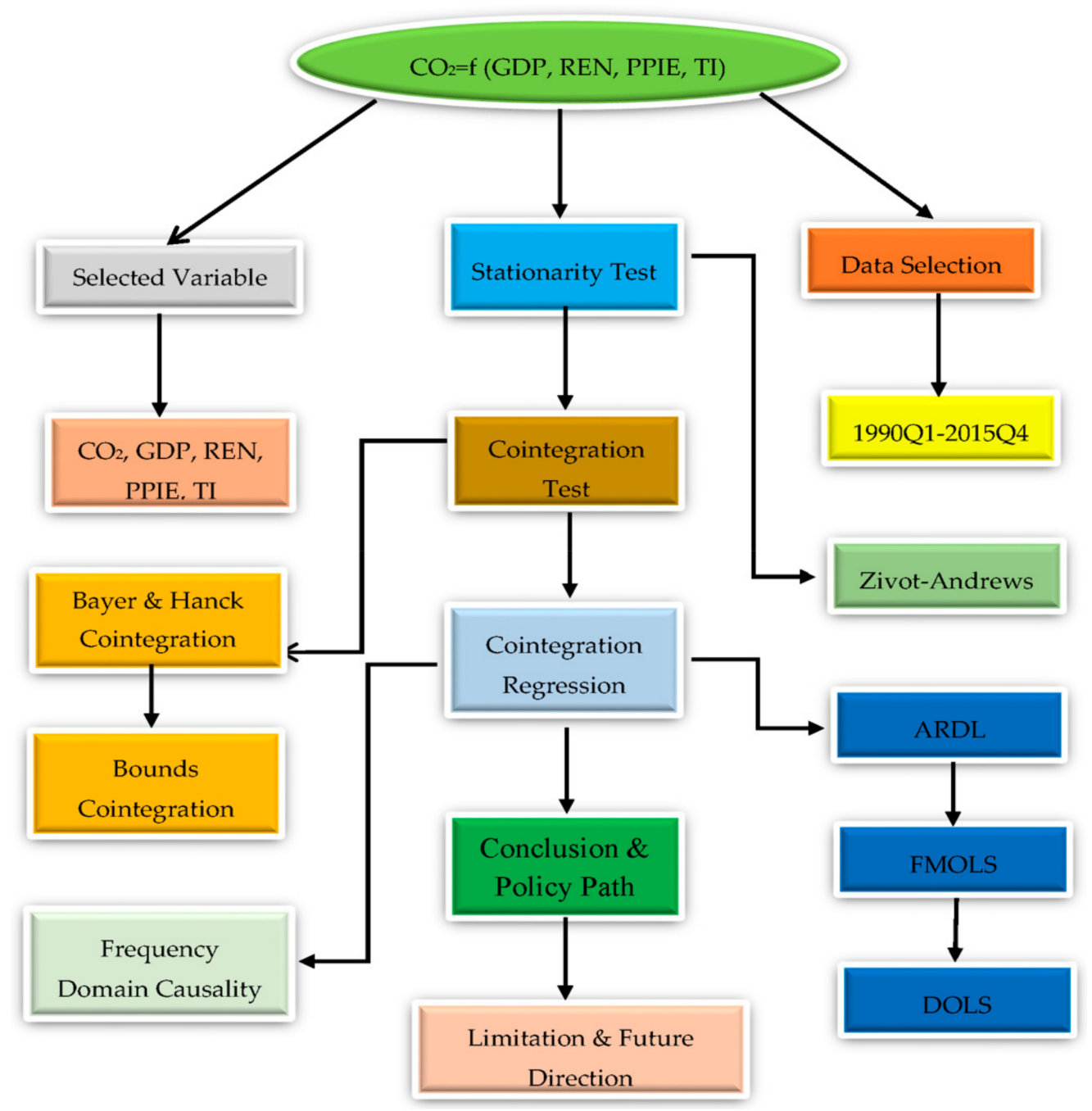

Figure 1. Analysis Flow Chart

In Figure 1 above, $\mathrm{CO}_{2}$, GDP, REN, PPIE and TI depicts $\mathrm{CO}_{2}$ emissions, economic growth, renewable energy consumption, Public-private partnership investment in energy, and technological innovation. Also, FMOLS, DOLS and ARDL depict fully modified ordinary least square, dynamic ordinary least square, and autoregressiove distributed lag.

\subsection{Techniques Employed}

\subsubsection{Unit Root Tests}

As suggested by [34-36], if there is evidence of a structural break in a series, the conventional unit root tests may yield misleading results. Based on this, the current study utilized [40] the unit root test to capture the stationarity characteristics and single structural breaks in the series.

\subsubsection{Bayer and Hanck Cointegration}

In order to unveil long-run cointegration among the parameters, we used the cointegration test used in [31], which merged the cointegration tests from [41-44]. As stated by [3], this cointegration test is centered on eradicating the needless multiple tests method to offer efficient approximations of the typical issues produced by other cointegration tests. In line with the work by [36], the Fisher's equation is illustrated as follows:

$$
\begin{gathered}
\mathrm{EG}-\mathrm{JOH}=-2[\ln (\mathrm{PEG})+\ln (\mathrm{PJOH})] \\
\mathrm{EG}-\mathrm{JOH}-\mathrm{BO}-\mathrm{BDM}=-2[\ln (\mathrm{PEG})+\ln (\mathrm{PJOH})+\ln (\mathrm{PBO})+\ln (\mathrm{PBDM})]
\end{gathered}
$$


where the significance levels from [43,44] are illustrated by PEG and PJOH, respectively. Banerjee et al.'s [42,43] significance levels are represented by PBO and PBDM, respectively.

\subsubsection{ARDL Approach}

The autoregressive distributed lag (ARDL) bounds test developed by $[45,46]$ was used to capture the long-run cointegration associations between the dependent and independent variables. The benefits of the ARDL bounds model over the other conventional or traditional cointegration techniques are as follows: (i) it can be used when there is a mixed order of integration; (ii) it incorporates both short- and long-run coefficients simultaneously; (iii) it fits perfectly for small sample sizes; (iv) it accommodates different lag lengths; (v) the autocorrelation problem is removed. The calculated F-statistics are compared to the critical values for the lower and upper bounds. When the calculated F-statistics are below these values, the null hypothesis is not rejected; when the calculated F-statistics are greater, the null hypothesis is rejected, showing a long-run relationship among the variables. Equation (6) below explains the ARDL bounds model:

$$
\begin{gathered}
\Delta \mathrm{CO}_{2 \mathrm{t}}=\vartheta_{0}+\sum_{\mathrm{i}=1}^{\mathrm{t}} \vartheta_{1} \mathrm{CO}_{2 \mathrm{t}-\mathrm{i}}+\sum_{\mathrm{i}=1}^{\mathrm{t}} \vartheta_{2} \mathrm{GDP}_{\mathrm{t}-\mathrm{i}}+\sum_{\mathrm{i}=1}^{\mathrm{t}} \vartheta_{3} \mathrm{PPIE}_{\mathrm{t}-\mathrm{i}}+\sum_{\mathrm{i}=1}^{\mathrm{t}} \vartheta_{4} \mathrm{REN}_{\mathrm{t}-\mathrm{i}}+\sum_{\mathrm{i}=1}^{\mathrm{t}} \vartheta_{5} \mathrm{TI}_{\mathrm{t}-\mathrm{i}}+\beta_{1} \mathrm{CO}_{2 \mathrm{t}-\mathrm{i}}+\beta_{2} \mathrm{GDP}_{\mathrm{t}-\mathrm{i}} \\
+\beta_{3} \mathrm{PPIE}_{\mathrm{t}-\mathrm{i}}+\beta_{4} \mathrm{REN}_{\mathrm{t}-\mathrm{i}}+\beta_{5} \mathrm{TI}_{\mathrm{t}-\mathrm{i}} \varepsilon_{\mathrm{t}}
\end{gathered}
$$

The null and alternative hypotheses show no cointegration and evidence of cointegration, respectively. We fail to accept the null hypothesis if the F-statistics are greater than the critical lower and upper bound values. Equations (7) and (8) illustrate the null and alternative hypotheses, respectively:

$$
\begin{aligned}
& H_{0}=\vartheta_{1}=\vartheta_{2}=\vartheta_{3}=\vartheta_{4}=\vartheta_{5} \\
& H_{a} \neq \vartheta_{1} \neq \vartheta_{2} \neq \vartheta_{3} \neq \vartheta_{4} \neq \vartheta_{5}
\end{aligned}
$$

where $H_{0}$ denotes the null hypothesis and $H_{a}$ illustrates the alternative hypothesis.

After the long-run relationship is established, the ARDL model determines the error correction model (ECM). This is derived by estimating the model's short-run parameters by applying the ECM. Hence, incorporating the ECM model into our short-run parameters of the ARDL model would result in Equation (9), as follows:

$$
\begin{aligned}
\Delta \mathrm{CO}_{2 \mathrm{t}}=\vartheta_{0}+ & \sum_{\mathrm{i}=1}^{\mathrm{t}} \vartheta_{1} \mathrm{CO}_{2 \mathrm{t}-\mathrm{i}}+\sum_{\mathrm{i}=1}^{\mathrm{t}} \vartheta_{2} \mathrm{GDP}_{\mathrm{t}-\mathrm{i}}+\sum_{\mathrm{i}=1}^{\mathrm{t}} \vartheta_{3} \mathrm{PPIE}_{\mathrm{t}-\mathrm{i}}+\sum_{\mathrm{i}=1}^{\mathrm{t}} \vartheta_{4} \mathrm{REN}_{\mathrm{t}-\mathrm{i}}+\sum_{\mathrm{i}=1}^{\mathrm{t}} \vartheta_{5} \mathrm{TI}_{\mathrm{t}-\mathrm{i}}+\beta_{1} \mathrm{CO}_{2 \mathrm{t}-\mathrm{i}} \\
& +\beta_{2} \mathrm{GDP}_{\mathrm{t}-\mathrm{i}}+\beta_{3} \mathrm{PPIE}_{\mathrm{t}-\mathrm{i}}+\beta_{4} \mathrm{REN}_{\mathrm{t}-\mathrm{i}}+\beta_{5} \mathrm{TI}_{\mathrm{t}-\mathrm{i}}+\varphi \mathrm{ECT}_{\mathrm{t}-\mathrm{i}}+\varepsilon_{\mathrm{t}}
\end{aligned}
$$

where $\theta_{i=5}$ denotes the short-run coefficients, $\varepsilon_{t}$ stands for the error term, $\beta_{i=5}$ denotes coefficients in the long run, $\mathrm{t}$ represents the lag lengths, and $\mathrm{ECT}_{\mathrm{t}-\mathrm{i}}$ denotes the error correction term. Here, $\omega$ denotes the ECM coefficients. As a robustness check for the ARDL long-run estimation, the present research utilized dynamic ordinary least square (DOLS) and fully modified ordinary least square (FMOLS).

\subsubsection{Breitung and Candelon Causality Test}

The present study also aimed to identify the causal effects of economic growth, renewable energy consumption, Public-private partnership investment in energy, and technological innovation on $\mathrm{CO}_{2}$ emissions in at different frequencies in East Asia and Pacific region. Thus, the frequency domain causality test was deployed in this study. "The key distinction between the time domain method and the frequency domain method is that the time domain method informs us where a particular change arises inside a time series, while the frequency domain method evaluates the extent of a specific variation in a time series" [4]. The frequency domain allows the small sample data to eliminate seasonal variations [15]. The frequency domain test can also distinguish non-linearity and causality stages, whereas the test also identifies causality between parameters at different frequencies. 


\section{Findings and Discussion}

Table 2 depicts a short description of the parameters utilized in the current study. The natural logarithm of the $\mathrm{CO}_{2}$ emissions, Public-private partnership investment in energy, technological innovation, and economic growth variables was used in the present study. This was done to make the variables conform to normality requirements. $\mathrm{CO}_{2}$ emissions ranged from 0.4373 to 0.7989 , economic growth ranged from 3.6425 to 3.9727 , Public-private partnership investment in energy ranged from 8.9702 to 10.248, renewable energy consumption ranged from 13.021 to 25.611, and technology innovation ranged from 5.6150 to 6.2578 . Additionally, all parameters were close to zero, which showed that they conformed to normality requirements, as demonstrated by the kurtosis. Moreover, the Jarque-Bera $p$-values illustrated that only renewable energy consumption conforms to normality while $\mathrm{CO}_{2}$ emissions, Public-private partnership investment in energy, and technological innovation do not conform to normality.

Table 2. Descriptive statistics and codes.

\begin{tabular}{cccccc}
\hline Code & $\mathbf{C O}_{2}$ & PPIE & REN & TI & GDP \\
\hline Mean & 0.615011 & 9.746495 & 18.67766 & 5.887427 & 3.790594 \\
\hline Median & 0.594831 & 9.773148 & 18.63410 & 5.860891 & 3.772244 \\
\hline Maximum & 0.798975 & 10.24854 & 25.61144 & 6.257853 & 3.972720 \\
\hline Minimum & 0.437346 & 8.970217 & 13.02167 & 5.615098 & 3.642550 \\
\hline Std. Dev. & 0.125308 & 0.290827 & 4.307600 & 0.173711 & 0.099849 \\
\hline Skewness & 0.252250 & -0.512254 & 0.028726 & 0.326227 & 0.265700 \\
\hline Kurtosis & 1.495902 & 2.827269 & 1.345532 & 2.285823 & 1.777652 \\
\hline Jarque-Bera & 10.06732 & 4.317809 & 10.96226 & 3.742977 & 7.106077 \\
\hline Probability & 0.006515 & 0.115452 & 0.004165 & 0.153894 & 0.028637 \\
\hline
\end{tabular}

We used the unit root for this purpose, recognizing a single break in the variable. In this respect, in the midst of a structural break, the analysis utilized the Zivot-Andrew unit root test to catch the series of stationary characteristics. Table 3 demonstrates the unit root test results, with the outcomes illustrating that only the PPIE variable is stationary at this level. Furthermore, after taking the first difference, all the parameters are stationary.

Table 3. ZA test.

\begin{tabular}{cccccc}
\hline \multicolumn{7}{c}{ I(0) } \\
\hline CO2 & PPIE & REN & TI & GDP \\
\hline C\&T & -3.000 & $-5.061^{*}$ & -2.845 & -4.776 & -4.687 \\
\hline & $(2009 Q 2)$ & $(1999 Q 2)$ & $(2006 Q 2)$ & $(2009 Q 1)$ & $(1997 Q 4)$ \\
\hline C\&T & $-6.664^{* * *}$ & $-14.214^{* * *}$ & $-6.188^{* * *}$ & $-6.139 * * *$ & $-5.837^{* * *}$ \\
\hline & $(2001 Q 2)$ & $(2000 Q 2)$ & $(2002 Q 2)$ & $(2010 Q 3)$ & $(1999 Q 4)$ \\
\hline
\end{tabular}

Note: I(0) and I(1) illustrate the level and first difference, respectively; ${ }^{* * *}$ and * depict levels of significance of $10 \%$ and $1 \%$, respectively. $\mathrm{CO}_{2}$, PPIE, REN, TI and GDP depicts $\mathrm{CO}_{2}$ emissions, public-private investment in energy, renewable energy consumption, technological innovation, and economic growth.

The present study explores the cointegration features of indicators by employing the Bayer-Hanck combined cointegration test. Table 4 signifies the outcomes of the BayerHanck test. The results illustrate evidence of long-run cointegration at a 5\% significance level between $\mathrm{CO}_{2}$ emissions and Public-Private Partnership Investment in Energy, renewable energy consumption, technological innovation, and economic growth. We also 
implemented the ARDL bounds test to verify the findings of the Bayer-Hanck test. The results of the ARDL bounds test are illustrated in Table 5. The empirical outcomes show that the indicators move together in the long run.

Table 4. Bayer-Hanck test.

\begin{tabular}{|c|c|c|c|}
\hline & Fisher Statistics & Fisher Statistics & Decision \\
\hline & EG-JOH & EG-JOH-BAN-BOS & \\
\hline \multirow[t]{2}{*}{$\mathrm{CO}_{2}=\mathrm{f}($ GDP PPIE, REN, TI $)$} & $14.304^{* *}$ & $26.794 * *$ & There is cointegration \\
\hline & $\mathrm{CV}$ & $\mathrm{CV}$ & \\
\hline $5 \%$ & 10.576 & 20.143 & \\
\hline
\end{tabular}

Table 5. Bounds test.

\begin{tabular}{|c|c|c|c|c|c|}
\hline F-Statistics & $\chi^{2} \mathrm{ARCH}$ & $\chi^{2}$ RESET & $\chi^{2}$ Normality & \multicolumn{2}{|c|}{$\chi^{2} \mathrm{LM}$} \\
\hline $11.76^{*}$ & $1.05(0.42)$ & $0.19(0.84)$ & $0.26(0.87)$ & \multicolumn{2}{|c|}{$0.82(0.69)$} \\
\hline \multicolumn{2}{|c|}{$10 \%$} & \multicolumn{2}{|c|}{$5 \%$} & \multicolumn{2}{|c|}{$1 \%$} \\
\hline LB & UB & LB & UB & LB & UB \\
\hline 2.204 & 3.320 & 2.615 & 3.891 & 3.572 & 5.112 \\
\hline
\end{tabular}

Note: * represent a $1 \%$ level of significance; LB and UB illustrate lower and upper bounds.

After cointegration between the parameters was established, we explored the long-run interconnections between $\mathrm{CO}_{2}$ emissions and technological innovation, renewable energy consumption, economic growth, and Public-Private Partnership Investment in Energy. Therefore, we utilized the ARDL technique to examine the impacts of Public-Private Partnership Investment in Energy, renewable energy consumption, economic growth, and technological innovation on $\mathrm{CO}_{2}$ emissions in the context of East Asian and Pacific region. The results of the ARDL long- and short-run estimates are depicted in Table 6. The ARDL long-run and short-run estimation outcomes are depicted as follows. Firstly, as anticipated, the finding revealed the negative interconnection between $\mathrm{CO}_{2}$ emissions and technological innovation in East Asia and the Pacific. This implies that if other indicators are kept constant, a $1 \%$ increase in technological innovation will decrease $\mathrm{CO}_{2}$ emissions by $0.08 \%$. Therefore, technological innovation significantly enhances the quality of the environment. Without imposing high taxes to improve environmental quality, nations can embrace initiatives to enhance innovation and reduce environmental degradation. This outcome is in line with prior studies by [3,23], who found that technological innovation enhances environmental sustainability. Secondly, renewable energy consumption has a negative impact on $\mathrm{CO}_{2}$ emissions, which means a surge in renewable energy mitigates $\mathrm{CO}_{2}$ emissions. This is because green energies use safer and pure energy sources that are secure and fulfill existing and prospective requisites; they are also a means of reducing $\mathrm{CO}_{2}$ emissions. This analytical outcome is consistent with previous studies $[3,26]$, who established that renewable energy consumption mitigates environmental degradation.

Third, there is evidence of a positive association between economic growth and $\mathrm{CO}_{2}$, emissions, which means that a surge in economic growth harms environmental quality. This outcome is in agreement with prior studies $[47,48]$, which found a positive interaction between economic growth and $\mathrm{CO}_{2}$ emissions. The main motive behind the positive interconnection is that the critical sources for agriculture and industry are fossil fuels, leading to an increase in economic expansion and a decrease in environmental quality [49-53]. The increase in environmental emissions due to industrial growth in East Asia and the Pacific region is associated with the development of infrastructure, the advancement of commerce, and economic capitalization, which positively affect investment and economic activity, and therefore increase energy consumption $[3,38,45]$. This outcome is in line with past studies $[7,9,27]$, who established that economic growth harms environmental sustainability. 
Fourthly, in Table 6, the Public-Private Partnership Investment in Energy exerts a positive effect on $\mathrm{CO}_{2}$ emissions in the East Asia and Pacific regions. This implies that if other parameters remain constant, a surge in Public-Private Partnership Investment in Energy would decrease environmental sustainability by $0.029 \%$. This finding aligns with the study by [7], who established a positive association between public-private partnership investment in energy and $\mathrm{CO}_{2}$ emissions. Nonetheless, the outcome does not correspond with the study by [5], which found a negative association between Public-Private Partnership Investment in Energy and $\mathrm{CO}_{2}$ emissions.

Table 6. ARDL long-run and short-run outcomes.

\begin{tabular}{|c|c|c|}
\hline Variables & Long-Run & Short-Run \\
\hline PPIE & $\begin{array}{c}0.029 \\
(4.183) \\
{[0.001]^{* * *}}\end{array}$ & $\begin{array}{c}0.029 \\
(7.820) \\
{[0.000]^{* * *}}\end{array}$ \\
\hline REN & $\begin{array}{c}-0.013 \\
(-5.060) \\
{[0.000]^{* * *}}\end{array}$ & $\begin{array}{c}-0.713503 \\
(-7.102) \\
{[0.000]^{* * * *}}\end{array}$ \\
\hline $\mathrm{TI}$ & $\begin{array}{c}-0.081 \\
(-2.501) \\
{[0.024]^{* *}}\end{array}$ & $\begin{array}{c}-0.081 \\
(-2.365) \\
{[0.037]^{* *}}\end{array}$ \\
\hline GDP & $\begin{array}{c}1.474 \\
(5.224) \\
{[0.0020]^{* * *}}\end{array}$ & $\begin{array}{c}1.474 \\
(7.965) \\
{[0.000]^{* * *}}\end{array}$ \\
\hline C & $\begin{array}{c}-2.347 \\
(-3.191) \\
{[0.008]^{* * *}}\end{array}$ & $\begin{array}{c}-1.824 \\
(-3.097) \\
{[0.002]^{* * *}}\end{array}$ \\
\hline ECM & \multicolumn{2}{|c|}{$\begin{array}{c}-0.85 \\
(-8.955) \\
{[0.000]^{* * *}}\end{array}$} \\
\hline $\mathrm{R}^{2}$ & \multicolumn{2}{|c|}{0.99} \\
\hline Adj- $R^{2}$ & \multicolumn{2}{|c|}{0.98} \\
\hline
\end{tabular}

Note: Significance levels of $1 \%$, and $5 \%$ are depicted by ${ }^{* * *}$ and ${ }^{* *}$, respectively. Values inside () and [] are t-sataistic and probability values respectively.

As anticipated, the ECM was statistically significant at the right level, which was -0.90 . This illustrates that short-run shocks can be adjusted back to the equilibrium in the long run by $85 \%$. Moreover, the $\mathrm{R}^{2}$ and adjusted $\mathrm{R}^{2}$ were 0.99 and 0.98 , respectively. This implies that the independent variables (technological innovation, renewable energy consumption, public-private partnerships in energy, and renewable energy consumption) explained $99 \%$ of the dependent variable $\left(\mathrm{CO}_{2}\right.$ emissions). The remaining $1 \%$ was attributed to the error term. Furthermore, we conducted various diagnostic tests, such as normality, serial correlation, Ramsey, and heteroscedasticity tests. The outcomes showed that the model suffered from no misspecification or serial correlation, and the residuals were normally distributed. Furthermore, CUSUM and CUSUM of square in Figure $2 \mathrm{a}, \mathrm{b}$ show that the model is stable. To confirm the ARDL long-run estimation outcomes, the current study utilized FMOLS and DOLS long-run estimators. The empirical findings of the DOLS and FMOLS are presented in Table 7. The results conformed to the ARDL long-run estimation. 


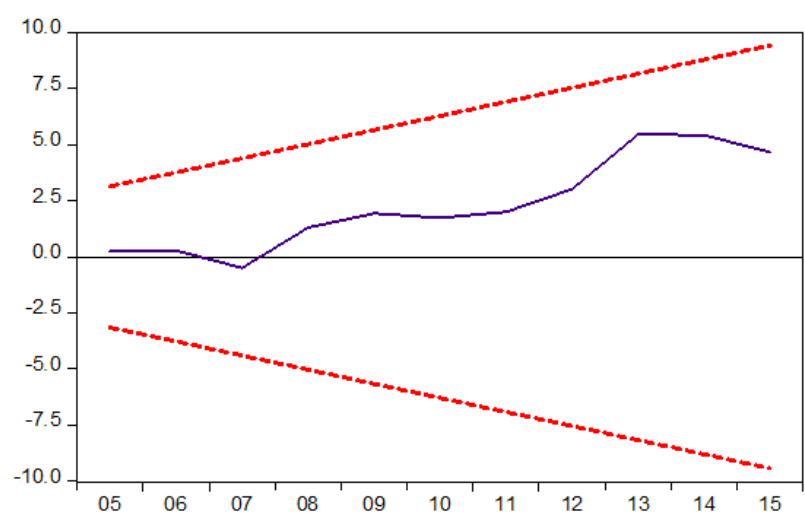

- CUSUM --- $5 \%$ Signific ance

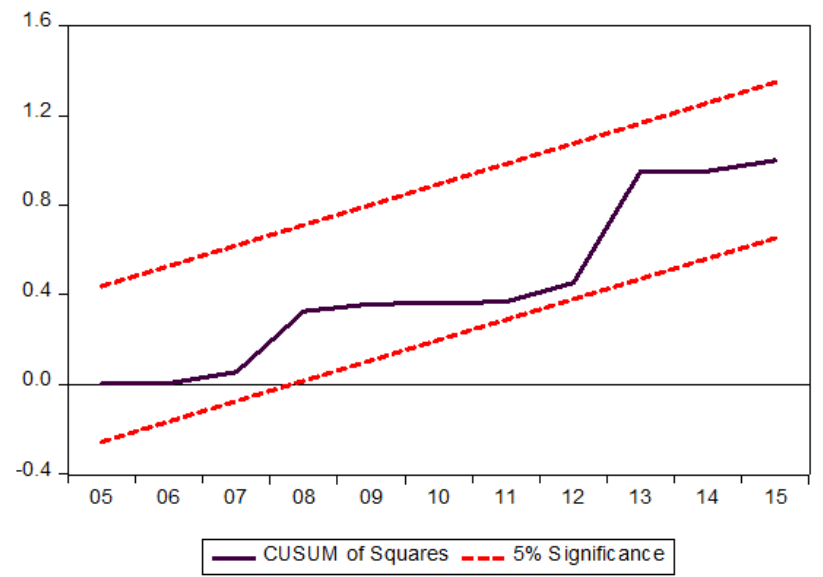

Figure 2. (top) CUSUM and (bottom) CUSUM Sq.

Table 7. FMOLS and DOLS.

\begin{tabular}{ccc}
\hline Variables & FMOLS & DOLS \\
\hline \multirow{2}{*}{ PPIE } & 0.036 & 0.037 \\
& -4.146 & -2.574 \\
& {$[0.000]^{* * *}$} & {$[0.012]^{* *}$} \\
\hline \multirow{2}{*}{ REN } & -0.013 & -0.014 \\
& $(-5.060)$ & $(-4.572)$ \\
& {$[0.000]^{* * *}$} & {$[0.000]^{* * *}$} \\
\hline \multirow{2}{*}{ TI } & -0.242 & -0.239 \\
& $(-2.423)$ & $(-2.114)$ \\
GDP & {$[0.016]^{* *}$} & {$[0.037]^{* *}$} \\
\hline \multirow{2}{*}{ C } & 1.016 & 0.987 \\
& -3.816 & -3.282 \\
& {$[0.002]^{* * *}$} & {$[0.001]^{* * *}$} \\
\hline R-squared & -1.917 & -1.824 \\
SE. & $(-3.762)$ & {$[-3.097)$} \\
\hline
\end{tabular}

Note: Significance levels of $1 \%$ and $5 \%$ are depicted by ${ }^{* * *}$ and ${ }^{* *}$, respectively. FMOLS and DOLS represents fully modified ordinary least square and dynamic ordinary least square respectively. Values inside () and [] are $\mathrm{t}$-sataistic and probability values respectively.

After the long-run effects had been identified, we utilized the Breitung and Candelon causality test to capture causal linkages between economic growth, technological innova- 
tion, Public-Private Partnership Investment in Energy, renewable energy consumption, and $\mathrm{CO}_{2}$ emissions at various frequencies. The advantage of the Breitung and Candelon causality test is that it can capture causality in the short, medium, and long term. Table 8 notes that the null hypothesis for Public-Private Partnership Investment in Energy could not be rejected in the short, medium, and long run because Public-Private Partnership Investment in Energy Granger cause $\mathrm{CO}_{2}$ emissions. This infers that Public-Private Partnership Investment in Energy are essential determinants of $\mathrm{CO}_{2}$ emissions in the long term in the East Asia and Pacific region. This is endorsed by the assertion that Public-Private Partnership Investment in Energy are crucial in domestic economic output and are also vital at the nation level for climate change [5]. In general, the transition of energy generation decentralization via public-private partnership in energy could also affect environmental sustainability by reducing carbon volume.

Table 8. Breitung and Candelon causality test.

\begin{tabular}{|c|c|c|c|c|c|c|}
\hline \multirow[b]{2}{*}{$\begin{array}{c}\text { Causality } \\
\text { Path }\end{array}$} & \multicolumn{2}{|c|}{ Long-Run } & \multicolumn{2}{|c|}{ Medium-Run } & \multicolumn{2}{|c|}{ Short-Run } \\
\hline & $\mathrm{w}_{\mathrm{i}}=0.01$ & $w_{i}=0.05$ & $w_{i}=1.00$ & $\mathrm{w}_{\mathrm{i}}=1.50$ & $w_{i}=2.00$ & $\mathrm{w}_{\mathrm{i}}=2.50$ \\
\hline $\begin{array}{c}\mathrm{PPIE} \rightarrow \\
\mathrm{CO}_{2}\end{array}$ & $\begin{array}{c}7.089 * * * \\
(0.028)\end{array}$ & $\begin{array}{l}7.087^{* * * *} \\
(00.028)\end{array}$ & $\begin{array}{c}0.285 \\
(0.866) \\
\end{array}$ & $\begin{array}{c}0.261 \\
(0.877) \\
\end{array}$ & $\begin{array}{c}0.622 \\
(0.732) \\
\end{array}$ & $\begin{array}{c}0.807 \\
(0.667) \\
\end{array}$ \\
\hline $\begin{array}{c}\mathrm{REC} \rightarrow \\
\mathrm{CO}_{2}\end{array}$ & $\begin{array}{c}12.758^{* * *} \\
(0.001)\end{array}$ & $\begin{array}{c}12.743^{* * *} \\
(0.001)\end{array}$ & $\begin{array}{c}1.599 \\
(0.449)\end{array}$ & $\begin{array}{c}1.636 \\
(0.441) \\
\end{array}$ & $\begin{array}{c}1.683 \\
(0.431) \\
\end{array}$ & $\begin{array}{c}1.707 \\
(0.425)\end{array}$ \\
\hline $\mathrm{TI} \rightarrow \mathrm{CO}_{2}$ & $\begin{array}{l}7.195 * * \\
(0.027)\end{array}$ & $\begin{array}{l}7.191^{* *} \\
(0.027)\end{array}$ & $\begin{array}{c}0.212 \\
(0.899)\end{array}$ & $\begin{array}{c}0.466 \\
(0.792)\end{array}$ & $\begin{array}{c}0.003 \\
(0.998)\end{array}$ & $\begin{array}{c}0.486 \\
(0.784)\end{array}$ \\
\hline$\underset{\mathrm{GDP}}{\mathrm{CO}} \rightarrow$ & $\begin{array}{l}7.179 * * \\
(0.027)\end{array}$ & $\begin{array}{l}6.684^{* *} \\
(0.035)\end{array}$ & $\begin{array}{c}11.008^{* * * *} \\
(0.004)\end{array}$ & $\begin{array}{c}15.283^{* * *} \\
(0.000)\end{array}$ & $\begin{array}{c}14.798^{* * *} \\
(0.000)\end{array}$ & $\begin{array}{c}22.017^{* * * *} \\
(0.000)\end{array}$ \\
\hline
\end{tabular}

Moreover, in the long term, at a significance level of $5 \%$, technological innovation Grange cause $\mathrm{CO}_{2}$ emissions in the East Asia region. This illustrates that technological innovation can predict $\mathrm{CO}_{2}$ emissions. This result aligns with past studies $[3,5,7]$. This infers that the East Asia and Pacific regions should pay attention to advanced technology in the environment when upgrading their technological innovation level and should guide the development of technologies conducive to environmental protection. At the same time, environmental protection issues should be discussed in greater depth in terms of economic, political, and social globalization with other high-technology regions, such as Europe and North America. Their respective technological advantages should be used to jointly promote the transformation of technological innovation.

Furthermore, in the long term, renewable energy consumption causes $\mathrm{CO}_{2}$, which shows that renewable energy consumption can significantly predict $\mathrm{CO}_{2}$ emissions in the East Asia and Pacific region. This outcome is in line with prior studies $[3,23]$ that established unidirectional causality from renewable energy consumption to $\mathrm{CO}_{2}$ emissions. Additionally, in the long, medium, and short term, at a significant level of $5 \%$ and $1 \%$, respectively, economic growth causes $\mathrm{CO}_{2}$ emissions. This infers that economic growth is a strong predictor of $\mathrm{CO}_{2}$ emissions. This outcome corresponds with past studies [37,50].

\section{Conclusions}

Environmental sustainability is one of the problems facing mankind today. Therefore, environmental sustainability has attracted the attention of international organizations, policymakers, and researchers around the world. To the investigator's knowledge, the causal and long-run effects of technological innovation, public-private partnerships in energy, and renewable energy consumption on environmental sustainability in the East Asian and Pacific regions have not been comprehensively explored while taking into account the role of economic growth. Thus, the present study aimed to close this literature gap, using 
Bayer-Hanck cointegration, dynamic ordinary least square (DOLS), fully modified ordinary least square (FMOLS), autoregressive distributed lag (ARDL), and frequency domain causality tests to investigate the relationships between technological innovation, publicprivate partnership in energy, and renewable energy consumption on $\mathrm{CO}_{2}$ emissions. The outcomes from bounds and Bayer and Hanck cointegration tests revealed that there are cointegrated interconnections between economic growth, $\mathrm{CO}_{2}$ emissions, technological innovation, renewable energy consumption, and public-private investment in energy. The outcomes from ARDL, FMOLS, and DOLS long-run estimators showed that technological innovation and renewable energy consumption are positively associated with environmental sustainability. In contrast, public-private partnerships in energy and economic growth mitigate environmental sustainability in the East Asian and Pacific region. Furthermore, the study utilized the frequency domain causality test. The advantage of this test is that it can capture causality at different frequencies. The outcomes showed that technological innovation, renewable energy consumption, public-private partnerships in energy, and renewable energy consumption are important predictors of environmental sustainability, especially in the long run. This indicates that when formulating environmental sustainability policies in the East Asia and Pacific region, policymakers and governments should take into account the influence of technological innovation, renewable energy consumption, public-private partnerships in energy, and renewable energy consumption.

Thus, as a policy recommendation, we recommend promoting renewable consumption by focusing more on technological innovation in the East Asia and Pacific countries. Furthermore, the governments of East Asian and Pacific countries should be careful when framing policies that increase growth, which will hamper environmental sustainability. Moreover, governments in this region can help markets by creating a clear policy structure that provides long-term value in terms of lowering greenhouse gas emissions and that continually encourages new technologies that enhance environmental quality, since renewable energy improves environmental sustainability by reducing $\mathrm{CO}_{2}$ emissions. Therefore, the East Asia region must recognize the role of renewable energy, which this analysis finds to be essential in reducing $\mathrm{CO}_{2}$ emissions, so as to ensure sustainability by transforming its current energy policies to encourage green energy sources and other energy-efficient technologies. Finally, policymakers in the East Asia and Pacific regions should actively promote research and development of low-carbon technologies, which are key in the transition to a low-carbon economy, along with the development of coal energy utilization technologies for carbon dioxide capture and storage.

Although this study provides significant empirical results, additional work should be performed in various regions. Although the present utilized sound econometric techniques, the major limitation in this empirical analysis is the unavailability of data beyond the period of study. Lastly, future studies should conduct similar studies using different regions and different environmental sustainability proxies.

Author Contributions: Conceptualization, T.S.A. and D.K.; methodology, D.K. and T.S.A.; software, T.S.A. and S.Y.G.; validation, R.A.C.; formal analysis, R.A.C. and D.K.; investigation; T.S.A. and D.K.; resources, T.S.A.; data curation, S.Y.G.; writing-original draft preparation, D.K., T.S.A., and S.Y.G.; writing-review and editing R.A.C. and D.K.; visualization, R.A.C. and D.K.; supervision, R.A.C. and S.Y.G.; project administration, T.S.A. and D.K. All authors have read and agreed to the published version of the manuscript.

Funding: The project is funded under the program of the Minister of Science and Higher Education titled "Regional Initiative of Excellence" in 2019-2022, project number 018/RID/2018/19, the amount of funding PLN 10788 423,16.

Institutional Review Board Statement: The study was conducted according to the research guidelines approved by the Ethics Committees of Authors Institutions.

Informed Consent Statement: Not applicable.

Data Availability Statement: Not applicable. 
Acknowledgments: We confirmed that this manuscript has not been published elsewhere and is not under consideration by another journal. In addition, we also confirmed that this research did not receive any specific grants from funding agencies in the public, commercial, or not-for-profit sectors. We have no conflicts of interest to disclose. Ethical approval and informed consent do not applicable for this study.

Conflicts of Interest: The authors declare no conflict of interest.

\section{References}

1. Adebayo, T.S.; Odugbesan, J.A. Modeling $\mathrm{CO}_{2}$ emissions in South Africa: Empirical evidence from ARDL based bounds and wavelet coherence techniques. Environ. Sci. Pollut. Res. 2021, 28, 9377-9389. [CrossRef]

2. Adebayo, T.S.; Akinsola, G.D. Investigating the Causal Linkage Among Economic Growth, Energy Consumption and $\mathrm{CO}_{2}$ Emissions in Thailand: An Application of the Wavelet Coherence Approach. Int. J. Renew. Energy Dev. 2021, 10, 17-26. [CrossRef]

3. Kirikkaleli, D.; Adebayo, T.S. Do renewable energy consumption and financial development matter for en-vironmental sustainability? New global evidence. Sustain. Dev. 2020. [CrossRef]

4. Odugbesan, J.A.; Adebayo, T.S. The symmetrical and asymmetrical effects of foreign direct investment and financial development on carbon emission: Evidence from Nigeria. SN Appl. Sci. 2020, 2, 1-15. [CrossRef]

5. Shahbaz, M.; Shafiullah, M.; Papavassiliou, V.G.; Hammoudeh, S. The CO 2 -growth nexus revisited: A nonparametric analysis for the G7 economies over nearly two centuries. Energy Econ. 2017, 65, 183-193. [CrossRef]

6. Dinda, S. Production technology and carbon emission: Long-run relation with short-run dynamics. J. Appl. Econ. 2018, 21, 106-121. [CrossRef]

7. Khan, Z.; Ali, M.; Kirikkaleli, D.; Wahab, S.; Jiao, Z. The impact of technological innovation and public-private partnership investment on sustainable environment in China: Consumption-based carbon emissions analysis. Sustain. Dev. 2020. [CrossRef]

8. UCSUSA. Resources. 2020. Available online: https://www.ucsusa.org/resources/each-countrys-share-co2-emissions (accessed on 18 February 2020).

9. World Bank. World Development Indicators. 2021. Available online: http:/ / data.worldbank.org/ (accessed on 25 October 2020).

10. IPCC. Special Report on Global Warming of $1.5^{\circ}$ C. 2018. Available online: https://www.ipcc.ch/2018/10/08/summary-forpolicymakers-of-ipcc-special-report-on-global-warming-of-1-5c-approved-by-governments/ (accessed on 2 January 2021).

11. Datta, A. Public-private partnerships in India: A case for reform? Econ. Political Wkly. 2009, 2, 73-78.

12. David, D.; Venkatachalam, A. A Comparative Study on the Role of Public-Private Partnerships and Green Investment Banks in Boosting Low-Carbon Investments (No. 870); ADBI Working Paper Series; ADBI: Tokyo, Japan, 2018.

13. Dolla, T.; Laishram, B.S. Procurement of low carbon municipal solid waste infrastructure in India through public-private partnerships. Built Environ. Proj. Asset Manag. 2018, 8, 449-460. [CrossRef]

14. Patil, N.A.; Laishram, B. Public-private partnerships from sustainability perspective-a critical analysis of the Indian case. Int. J. Constr. Manag. 2016, 16, 161-174. [CrossRef]

15. Buonanno, P.; Carraro, C.; Galeotti, M. Endogenous induced technical change and the costs of Kyoto. Resour. Energy Econ. 2003, 25, 11-34. [CrossRef]

16. Wing, I.S. Induced Technical Change and the Cost of Climate Policy. 2003. Available online: https://dspace.mit.edu/handle/17 21.1/3648 (accessed on 22 January 2021).

17. Ganda, F. The impact of innovation and technology investments on carbon emissions in selected organisa-tion for economic Co-operation and development countries. J. Clean. Prod. 2019, 217, 469-483. [CrossRef]

18. Verdolini, E.; Vona, F.; Popp, D. Bridging the gap: Do fast-reacting fossil technologies facilitate renewable energy diffusion? Energy Policy 2018, 116, 242-256. [CrossRef]

19. Popp, D.; Hascic, I.; Medhi, N. Technology and the diffusion of renewable energy. Energy Econ. 2011, 33, 648-662. [CrossRef]

20. Alvarez-Herranz, A.; Balsalobre-Lorente, D.; Shahbaz, M.; Cantos, J.M. Energy innovation and renewable energy consumption in the correction of air pollution levels. Energy Policy 2017, 105, 386-397. [CrossRef]

21. Shahbaz, M.; Chaudhary, A.; Ozturk, I. Does urbanization cause increasing energy demand in Pakistan? Empirical evidence from STIRPAT model. Energy 2017, 122, 83-93. [CrossRef]

22. Wang, R.; Mirza, N.; Vasbieva, D.G.; Abbas, Q.; Xiong, D. The nexus of carbon emissions, financial development, renewable energy consumption, and technological innovation: What should be the priorities in light of COP 21 Agreements? J. Environ. Manag. 2020, 271, 111027. [CrossRef]

23. Kirikkaleli, D.; Adebayo, T.S. Do public-private partnerships in energy and renewable energy consumption matter for consumption-based carbon dioxide emissions in India? Environ. Sci. Pollut. Res. 2021, 1-14. [CrossRef]

24. Zhang, L.; Li, Z.; Kirikkaleli, D.; Adebayo, T.S.; Adeshola, I.; Akinsola, G.D. Modeling $\mathrm{CO}_{2}$ emissions in Malaysia: An application of Maki cointegration and wavelet coherence tests. Environ. Sci. Pollut. Res. 2021, 1-15. [CrossRef]

25. Balsalobre-Lorente, D.; Álvarez-Herranz, A.; Shahbaz, M. The long-term effect of economic growth, energy in-novation, energy use on environmental quality. In Energy and Environmental Strategies in the Era of Globalization; Springer: Cham, Switzerland, 2019; pp. 1-34.

26. Adebayo, T.S.; Akinsola, G.D.; Odugbesan, J.A.; Olanrewaju, V.O. Determinants of Environmental Deg-radation in Thailand: Empirical Evidence from ARDL and Wavelet Coherence Approaches. Pollution 2021, 7, 181-196. 
27. Umar, M.; Ji, X.; Kirikkaleli, D.; Xu, Q. COP21 Roadmap: Do innovation, financial development, and trans-portation infrastructure matter for environmental sustainability in China? J. Environ. Manag. 2020, 271, 111026. [CrossRef]

28. Lin, S.; Xiao, L.; Wang, X. Does air pollution hinder technological innovation in China? A perspective of innovation value chain. $J$. Clean. Prod. 2021, 278, 123326. [CrossRef]

29. Yu, Y.; Du, Y. Impact of technological innovation on $\mathrm{CO}_{2}$ emissions and emissions trend prediction on 'New Normal' economy in China. Atmos. Pollut. Res. 2019, 10, 152-161. [CrossRef]

30. Adebayo, T.S. Testing the EKC Hypothesis in Indonesia: Empirical Evidence from the ARDL-Based Bounds and Wavelet Coherence Approaches. Appl. Econ. J. 2021, 28, 1-23.

31. Aydoğan, B.; Vardar, G. Evaluating the role of renewable energy, economic growth and agriculture on $\mathrm{CO}_{2}$ emission in E7 countries. Int. J. Sustain. Energy 2019, 39, 335-348. [CrossRef]

32. Onyibor, K.; Adebayo, T.S.; Akinsola, G.D. The impact of major macroeconomic variables on foreign direct investment in Nigeria: Evidence from a wavelet coherence technique. SN Bus. Econ. 2021, 1, 1-24.

33. Kirikkaleli, D.; Athari, S.A. Time-frequency co-movements between bank credit supply and economic growth in an emerging market: Does the bank ownership structure matter? N. Am. J. Econ. Financ. 2020, 54, 101239. [CrossRef]

34. Kirikkaleli, D.; Adebayo, T.S.; Khan, Z.; Ali, S. Does globalization matter for ecological footprint in Turkey? Evidence from dual adjustment approach. Environ. Sci. Pollut. Res. 2020, 1-9. [CrossRef]

35. Adebayo, T.S.; Kalmaz, D.B. Ongoing Debate Between Foreign Aid and Economic Growth in Nigeria: A Wavelet Analysis. Soc. Sci. Q. 2020, 101, 2032-2051. [CrossRef]

36. Sadorsky, P. Energy consumption, output and trade in South America. Energy Econ. 2012, 34, 476-488. [CrossRef]

37. Bekun, F.V.; Alola, A.A.; Sarkodie, S.A. Toward a sustainable environment: Nexus between $\mathrm{CO}_{2}$ emis-sions, resource rent, renewable and nonrenewable energy in 16-EU countries. Sci. Total Environ. 2019, 657, 1023-1029. [CrossRef]

38. Lee, S.-J.; Yoo, S.-H. Energy consumption, $\mathrm{CO}_{2}$ emission, and economic growth: Evidence from Mexico. Energy Sources, Part. B: Econ. Plan. Policy 2016, 11, 711-717. [CrossRef]

39. Kalmaz, D.B.; Kirikkaleli, D. Modeling $\mathrm{CO}_{2}$ emissions in an emerging market: Empirical finding from ARDL-based bounds and wavelet coherence approaches. Environ. Sci. Pollut. Res. 2019, 26, 5210-5220. [CrossRef]

40. Zivot, E.; Andrews, D.W.K. Further evidence on the great crash, the oil-price shock, and the unit-root hy-pothesis. J. Bus. Econ. Stat. 2002, 20, 25-44. [CrossRef]

41. Engle, R.F.; Granger, C.W.J. Co-Integration and Error Correction: Representation, Estimation, and Testing. Econometrica 1987, 55, 251. [CrossRef]

42. Boswijk, H.P. Testing for an unstable root in conditional and structural error correction models. J. Econ. 1994, 63, 37-60. [CrossRef]

43. Banerjee, A.; Dolado, J.J.; Mestre, R. Error-correction Mechanism Tests for Cointegration in a Single-equation Framework. J. Time Ser. Anal. 1998, 19, 267-283. [CrossRef]

44. Johansen, S. Estimation and Hypothesis Testing of Cointegration Vectors in Gaussian Vector Autoregressive Models. Econometrica 1991, 59, 1551-1580. [CrossRef]

45. Pesaran, M.H.; Shin, Y. An autoregressive distributed-lag modelling approach to cointegration analysis. Econ. Soc. Monogr. 1998, 31, 371-413.

46. Pesaran, M.H.; Shin, Y.; Smithc, R.J. Bounds testing approaches to the analysis of level relationships. J. Appl. Econ. 2001, 16, 289-326. [CrossRef]

47. Adebayo, T.S. Revisiting the EKC hypothesis in an emerging market: An application of ARDL-based bounds and wavelet coherence approaches. SN Appl. Sci. 2020, 2, 1-15. [CrossRef]

48. Akadiri, S.S.; Bekun, F.V.; Sarkodie, S.A. Contemporaneous interaction between energy consumption, economic growth and environmental sustainability in South Africa: What drives what? Sci. Total Environ. 2019, 686, 468-475. [CrossRef]

49. Adedoyin, F.F.; Zakari, A. Energy consumption, economic expansion, and $\mathrm{CO}_{2}$ emission in the UK: The role of economic policy uncertainty. Sci. Total Environ. 2020, 738, 140014. [CrossRef] [PubMed]

50. Ozatac, N.; Gokmenoglu, K.K.; Taspinar, N. Testing the EKC hypothesis by considering trade openness, urbanization, and financial development: The case of Turkey. Environ. Sci. Pollut. Res. 2017, 24, 16690-16701. [CrossRef]

51. He, X.; Adebayo, T.S.; Kirikkaleli, D.; Umar, M. Analysis of Dual Adjustment Approach: Consump-tion-Based Carbon Emissions in Mexico. Sustain. Prod. Consum. 2021, 8, 22-41.

52. Adebayo, T.S. Do $\mathrm{CO}_{2}$ emissions, energy consumption and globalization promote economic growth? Empirical evidence from Japan. Environ Sci Pollut Res. 2021. [CrossRef]

53. Adebayo, T.S.; Kalmaz, D.B. Determinants of $\mathrm{CO}_{2}$ emissions: Empirical evidence from Egypt. Environ. Ecol. Stat. 2021, 1-24. [CrossRef] 